\title{
A New Approach Model in Post Graduate Training of Local Government Officers
}

\author{
István Tózsa \\ Corvinus University of Budapest, Hungary \\ E-mail: istvan.tozsa@uni-corvinus.hu
}

Received: May 12, 2015 Accepted: July 17, 2015 Published: November 9, 2015

doi:10.5296/jpmr.v1i1.7592 URL: http://dx.doi.org/10.5296/jpmr.v1i1.7592

\begin{abstract}
This study is based on the final report of Program ÁROP 2.2.22 entitled Training for the Local Governments of the Convergence Regions realized at the National University of Public Service, Hungary by the professional advisor of Program ÁROP 2.2.22.

In 2013-15 there was a new type of post graduate training elaborated and piloted in Hungary at the Institute of Executive Training and Continuing Education (VTKI) within the National University of Public Service (NKE). Although the pilot financed by the State Administration Reform Operative Program (ÁROP) had not lacked the previously established attempts to include interactivity in the training, it was the first to observe and apply the actual principles of the European Union 2020 expressed in the threefold criteria of economic growth: smartness, sustainability and inclusiveness. All of them are represented by a pillar of the program like e-learning, class training and field training with the inclusion of local society. According to the objectives of the program there were at least 10 thousand attendees from the civil service sphere set as project indicators, so it has been a large scale training program that took place in 2014 in Hungary. The following article shows the innovations included in this new approach model of post graduate training civil servants.
\end{abstract}

Keywords: e-learning, train the trainers, combined methods, local government post graduate training

\section{Background}

The relatively quickly transforming and changing legal and institutional structures of Central and Eastern European local governments at the end of the $20^{\text {th }}$ and the beginning of the $21^{\text {st }}$ centuries make the constant post graduate training of the local government officers and clerks 
unavoidable. Of course it was recognized by all organizations responsible for public administration training on both under and post graduate levels right after the political-economic transition of the post-communist Central and Eastern European countries at least two decades ago. New ways of training were being sought and tried to apply into the practice of post graduate education of the public sector.

In Hungary one of the first attempts included the adaption of the American interactive training program, the ICMA (International City - County Management Association). The National School of Public Administration (ÁF), one of the predecessors of the National University of Public Service, together with the National Association of Local Authorities (TÖOSZ) organized the first interactive training program financed by the US Government in 1995-1998. The main results of the cooperation included a train-the-trainers type course in which twenty young teachers of the School took part who later headed the training for one hundred mayors from all around Hungary coming from settlements with less than 25 thousand population. This initiation was the first to recognize the necessity of post graduate training first of all in the peripheries (today referred to as the convergence regions) especially in a country like Hungary, where owing to historical reasons the central or prime city (Budapest) and its gravity zone attract most of the business and human resource capital of the whole country. This interactive training aimed at bringing about a group of local authority leaders who were inclined to support a new way of local community building with making the citizens be aware of and sensitive to local matters and policy making. However, after the pilot it turned out that local social readiness was not mature enough and owing to the lack of interest in policy making the program could not develop its institutional framework (Dobos 1998, Tóth 2007).

A few years later in 2004 - 2007 there was another attempt to introduce the new type of interactive training both in under and post graduate higher education in the framework of the project entitled Structural and Content Innovations in the Higher Education of Public Administration (HEFOP 2008). It was a practice orientated development of teaching materials focusing on the social sensitivity of civil servants and including a sequence of interactive trainings carried out in the following topics: office conflicts, social facilitation, urban quality of life, project management, behavior influencing through interactive techniques, train the trainers methods. There were 10 local authorities included in the trainings and all together 385 civil servants took part in them. This project justified the need for interactive training. They found the ways how best practices were communicated, how problems were discussed and how their communication techniques did improve very useful.

These projects made the ground for a more complex attempt to introduce a wide scope training program which is interactive and socially more inclusive than the previous one. At the end of the 2000s and the beginning of the 2010s public administration as a whole anticipated and then went under a complex restructuring which postponed the innovations needed in post graduate training.

By 2013, however, interactive training techniques became so widespread in business courses that the education of post graduate public administration could not neglect them anymore and 
some pilots were carried out that proved the local social acceptance and readiness for the inclusive type, complex trainings revealed via studies by Dobos 2009a-b, Belényesi - Dobos 2010, Dobos $2011 \mathrm{a}-\mathrm{b}-\mathrm{c}$.

\section{Structure of the New Approach Model}

In 2013 the ÁROP (State Administration Reform Operative Program) launched a call for the post graduate training of the officers and administrative employees of local authorities in all Hungarian regions except the Central Hungarian one in and around Budapest the capital city. The program, supported by the European Union, was elaborated and opened in 2013 and it started in 2014. It has 3 pillars: the widest participation is offered by a group of e-learning courses (modules). The e-learning modules are open for all public servants, not only in the convergence regions, and the completion of any of these modules provide the public servants with 8 points that can be added to the compulsory amount of points that they have to collest5 in post graduate training in each three years as it is required by law (see Government Decree 2012). Several thousands of public servants can take any of these innovative courses. The second pillar represents the mainstream of innovation in introducing a training methodology that has got very few precedents in post graduate training. Some seventy local governments and settlements could apply for taking part in these interactive workshops with the recommendation of the State Secretariat responsible for Local Governments in the Ministry of the Interior. Finally the third pillar is a traditional training of some 300 participants providing a certificate entitled local government advisor. Though, this training is closely linked to the other two pillars, making up the combined and complex training system the structure of which is shown in Figure 1. The whole program has been hosted and managed by the Institute of Executive Training and Continuing Education (VTKI) within the National University of Public Service (NKE).

This training program can be considered new because it combines the traditional, well established post graduate training ( $3^{\text {rd }}$ pillar) with the new, smart technology based e-learning $\left(1^{\text {st }}\right.$ pillar) and another revolutionary approach represented by the idea of social inclusiveness in the operation of local government ( $2^{\text {nd }}$ pillar), and also, a sustainable aspect of spreading modern administrative knowledge $\left(1^{\text {st }}\right.$ pillar). Consequently all the three priorities of the Europe 2020 strategy are present in it. These priorities are manifested by smart, sustainable and inclusive growth (see Europe 2020).

Like abroad at many places, in Hungary there is an 'I don't care it's going to happen anyway' attitude perceived on part of the public service staff, and this this could be improved only if the training is inclusive enough to motivate clerks. According to the Members of the Guardian Local Government Network municipal staff does not have enough training to commission local public services in an effective way (see Fearn 2013). The survey said 77\% of the inquired said they needed more training possibilities to do their jobs in an appropriate way, while $14 \%$ of them said they had already been expected to perform workflows for which they did not have the necessary skills or knowledge. The situation must be similar in Central European countries, too. This is another reason why the following post graduate training model was invented introduced. 


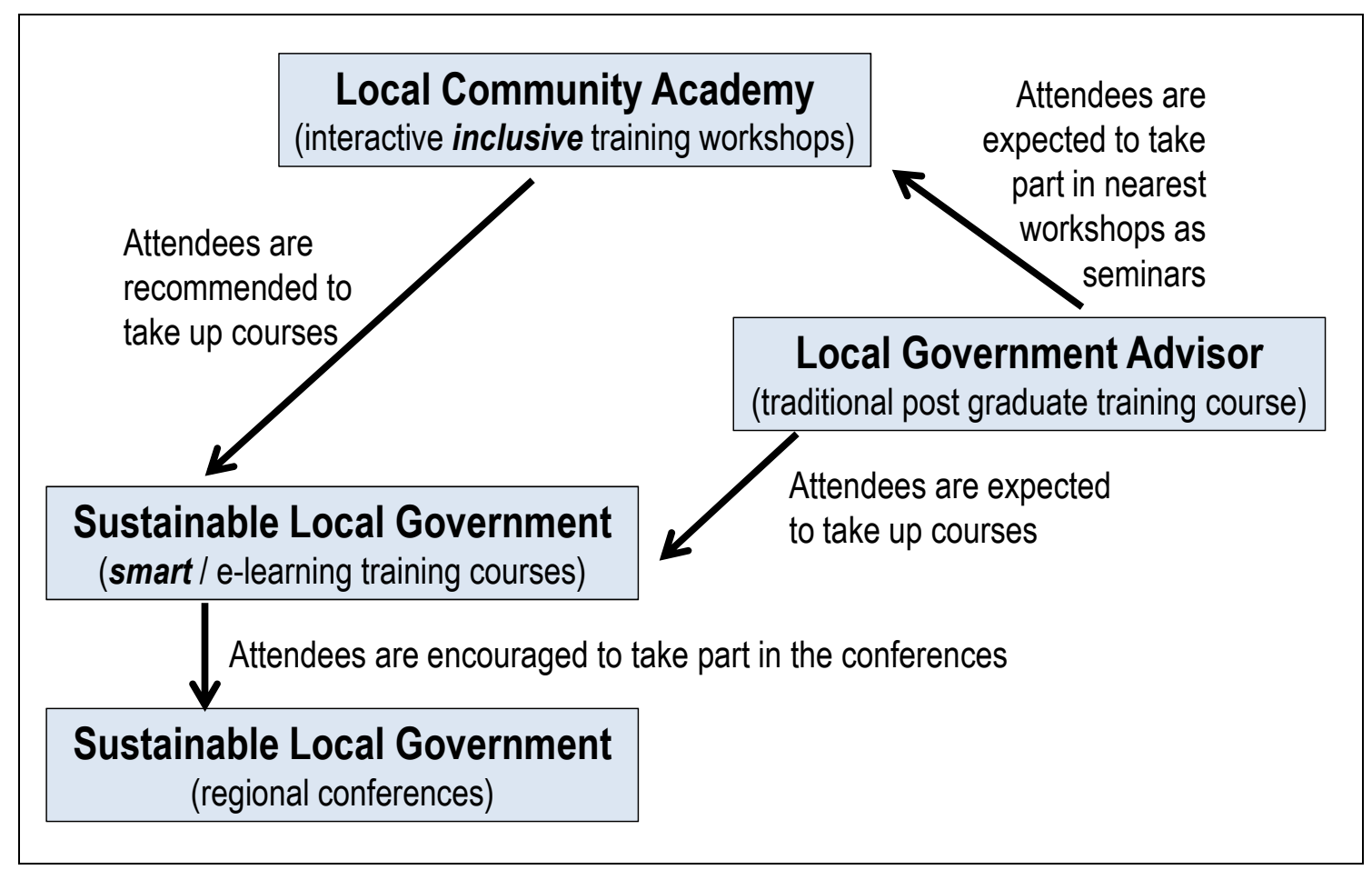

Figure 1. The combined structure of the new approach local government training model meets the Europe 2020 expectations regarding the priorities of smart, inclusive and sustainable growth

This consideration led the program constructors to regard this combined training as the flagship training program representing and meeting the most recent expectations on behalf of the Europe 2020 strategy in the field of post graduate training of civil servants. In the following there are the introductions to the three pillars of the program.

\section{Structure of Pillar One: Sustainable Local Government}

The objective of this pillar was to reach as many civil servants as possible from all over the country via a smart device, i.e. e-learning modules. Sustainability of local government development relies on the most important resource: knowledge. Therefore a basic criterion in post graduate training to frequent civil servants and local government officers with the latest knowledge achieved in the field of local government activity. Such knowledge was planned to be easily accessible for civil servants that could help them to obtain a wider horizon regarding modernization and the latest scientific findings.

Module 1 focuses on conflict management in local government offices. To overcome these conflicts occurring both in back and front office contexts, supports sustainability in local government operations. The latest findings at Harvard University USA proved the possibility of changing the destructive energies of these conflicts into a community building force supporting operation. 
Module 2 deals with the problems in building and developing a well working office structure of local governments which is also a prominent issue of sustainability. The organizational development of local government offices is a very useful knowledge to learn for all clerks and officers employed in the public sector.

Module 3 concentrates on the most compound local development issue: the local development plan, which all public servants have to be aware of independently of the fact what field they work in at the local government.

Module 4 gives information on e-government as the main driving force of the modernization of local government. This module contains the outlook of future development as far as the interactive three dimensional Second Life environments applied to local government are concerned to ensure the open mindedness of civil servants towards high technology solutions.

Module 5 shows the importance of strategy making in urbanization. It is perhaps the task of the local government that influences very strongly the quality of life of most local residents through shaping the form, functions and the aesthetic values of the settlement.

Module 6 contains information about the compulsory and facultative functions of the local government which again every employee is expected to know. Another aspect of this module introduces the students to the framework of financing of local governments. This module is the one with the most legal information.

Each module is composed of approximately 40 screens with roll on text, figures and many animations. In the first animation, instead of an introductory text and voice, there is an interview with the author in order to raise interest in the topic. Each module requires 8 hours learning to enable the student to pass the final exam at the end which is composed of 25 random test questions. There is a 'traditional' online tutoring service during the semester, however practice had shown that students used this service very exceptionally for something else than for asking technological helpdesk. For this reason in this program 'traditional' e-learning was backed not only by traditional online tutoring service, but by a 'traditional' textbook for those who prefer learning from paper based device to computer screens, by an intelligent tutoring service and by regional conferences. Figure 2 shows the structural parts of Sustainable Local Government Pillar.

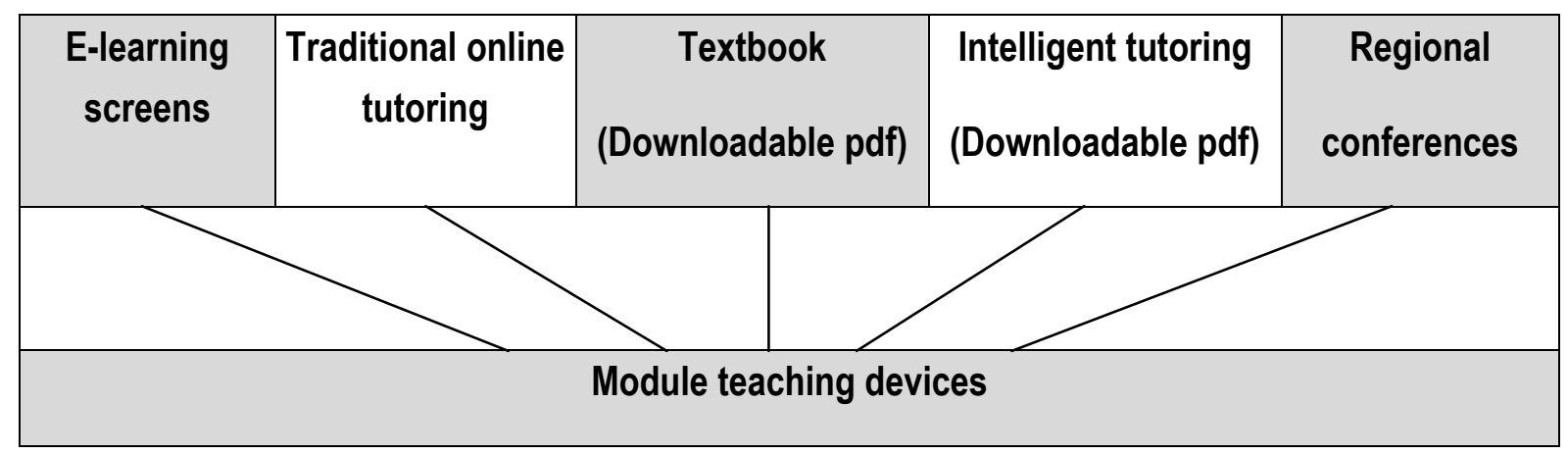

Figure 2. Interpretation of the teaching material of the e-learning modules in five educational forms 
The latter two can be considered as innovations in e-learning. There are some $60-80$ test questions for each module. The intelligent tutoring system is a downloadable file giving short definitions for all the test questions without identifying them, so studying this text can be a useful tool in passing the exam.

Another unique device is the organization of regional conferences at the major universities, as partners in the program, in the convergence regions encircling the central region and the capital city. During the conferences there were short introductions to each of the modules, delivered by the module authors themselves. Then, attached to these brief presentations there were more detailed papers given by local lecturers. Thus the regional relevancies of each module were manifested and the practical regional sides of the module topics were introduced. All those students who registered for any of the 6 modules of the Sustainable Local Government Pillar were sent a notification and invitation to these regional conferences depending on the location of their workplaces. Thus they were given the opportunity to listen to the interpretations of their teaching material seen in the specific environment of their own region. Also, they had the opportunity to meet and ask the module authors personally. The conferences took place in the autumn of 2014 in five university towns: Debrecen, Miskolc, Szeged, Pécs and Győr.

\section{Structure of Pillar Two: Local Community Academy}

The objective of the pillar was to bring about a methodology to build local community through training. This experiment aimed at creating training courses at 70 settlements in the convergence region that had administrative functions as micro regional hubs (centers of ridings or boroughs). However, the training was composed for participants from settlements with less than 5000 inhabitants each. The State Secretariat responsible for the Local Governments supported the application call and form among these small settlements. The content of the training was to develop a method for common strategy building and to demonstrate its operation and to get the participants to create one on their own, projected for their settlements. The constant trainers' control and the revision of the accomplished strategies were also included in the pillar's tasks. The main goal of this pillar has been to introduce a new approach to making local development strategies thus supporting the job of both the local municipality and the company commissioned to work out the local development plans. This is a new, collective and inclusive method to mobilize local community serving the interest of local development.

Tools in the training included discussions of the existing local development plans, filling in questionnaires, communication exercises, evaluating feedback and experts' opinions. Editing an independent homepage and publishing all kinds of items relevant to local strategy building (e.g. best practices, knowledge inventory, programs, feedback opinions, animations and film reports, promotions, local marketing devices, results of surveys). This pillar stands for the mainstream innovation represented in the whole Flagship Program, and it has its predecessors manifested in the ICAM and HEFOP projects in Hungary. The managers of the program trusted in a somewhat more mature, more open local society and local stakeholders than there 
were in the 1990s and 2000s in the Hungarian countryside as far as the readiness for inclusive local governance is concerned.

Structure of Activities and OUTPUTS of the Local Community Academy

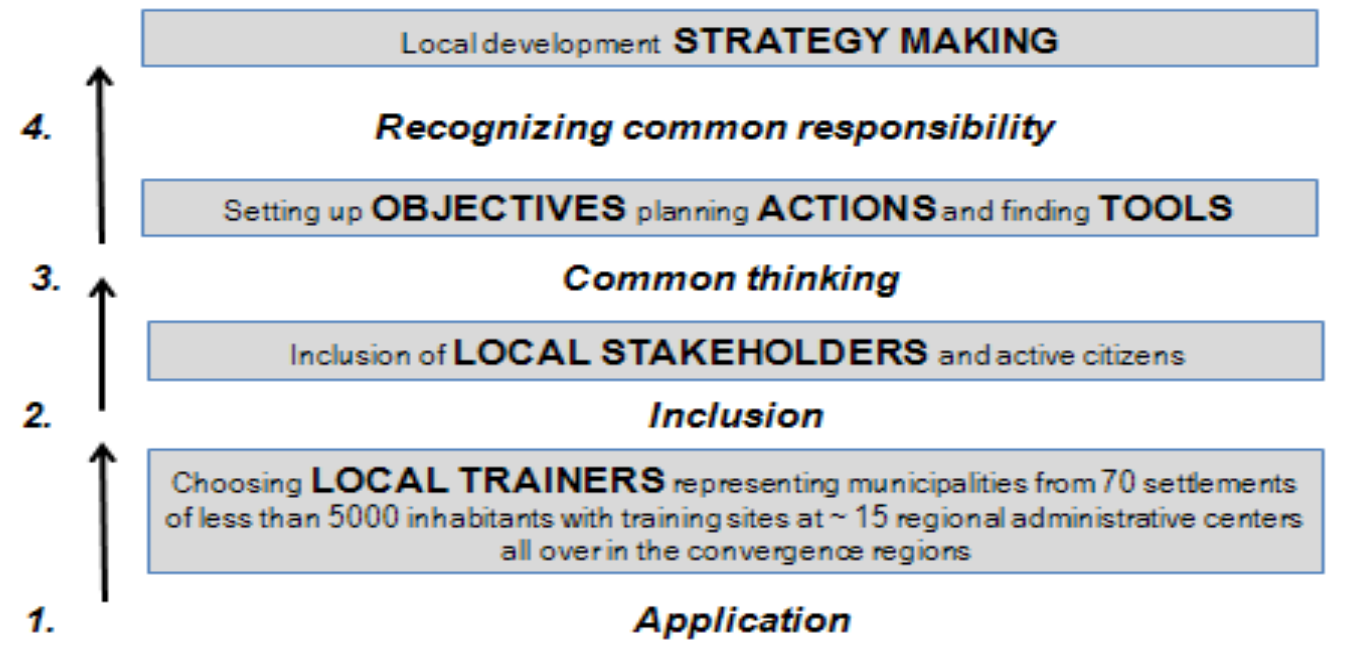

Figure 3. The training (3.) in the structure of the Local Community Academy showing the activities included and the outputs expected

\section{Structure of Pillar Three: Local Government Advisor}

The traditional classroom training part of the combined program aimed at strengthening the weaknesses experienced in the post graduate training choice and offer of the Institute of Executive Training and Continuing Education (VTKI). These fields included the operational issues, business activity and policy making of local governments. See Table 1.

Table 1. The curriculum of the Local Government Advisor training course

\begin{tabular}{|c|c|c|c|}
\hline Topic of subjects & \multicolumn{2}{|l|}{ Title of subjects - semester, number of classes } & $\begin{array}{l}\text { Type of } \\
\text { subjects }\end{array}$ \\
\hline \multirow{6}{*}{$\begin{array}{c}\text { Service and duty } \\
\text { performance of local } \\
\text { governments }\end{array}$} & \multicolumn{2}{|c|}{ Legal Status and Decision Competence of Local Governments - $\mathbf{1 . 1 6}$} & core \\
\hline & Management of Public Services in Transition Economy - & 1.16 & core \\
\hline & Organizational Development of Local Governments - & 1.08 and 2.08 & special \\
\hline & Urban Planning and Development - & 2.16 & special \\
\hline & Urban Marketing and Tourism & 2.08 & special \\
\hline & E-Government Modernization - & 2.12 & special \\
\hline
\end{tabular}


Public policy of local governments

Local Minority Governments, Migration, Refugee Affairs -

special

Local Environmental Policy -

\begin{tabular}{lcccc} 
& Local Environmental Policy - & $\mathbf{2 . 0 8}$ & special \\
\hline $\begin{array}{c}\text { Economy and business } \\
\text { of local governments }\end{array}$ & Local Government Business - & $\mathbf{1 . 1 2}$ & core \\
\hline
\end{tabular}

Communication of

local governments

Inclusive Local Government -

1.08 and 2.04

special

Total: 4 topics

Total: 12 subjects ( 4 core ones; 8 special ones)

Total number of classes 120

Number of semesters: 2

The contents of the above subjects have been elaborated partly by the professors of the National University of Public Service and the Corvinus University of Budapest and partly by the experts of the State Secretariat responsible for Local Governments in the Ministry of the Interior.

As stated previously (see Figure 1), the training course is strongly linked to the Local Community Academy workshops (Pillar 2) and to the Sustainable Local Government e-learning modules (Pillar 1). Registered students have to take part in the Local Community Academy workshops as compulsory seminars. The subject responsible for it is Inclusive Local Government. Registered students also have to accomplish at least one module from the Sustainable Local Government program as a practical piece of work.

Unlike to all previous post graduate training programs, this pillar had the privilege of publishing textbooks of all the 12 subjects. Thus quite a home library of 12 volumes was published in the beginning of 2015 when the program was accomplished.

\section{Completion of the New Approach Model}

The Flagship Program took place in 2014. The first to launch was Pillar Three with 300 participants from the convergence regions in February; the second was Pillar One (e-learning) dedicated to at least 9000 civil servants from the convergence regions, March, while the workshops needed more time to organize and thus Pillar Two started in earnest in September with a few participants from 70 local authorities from the convergence regions. Certifications, diplomas were issued in February 2015. The accomplishment of this Program has established the methodological grounds of a new concept post graduate training of the civil servant employees of the local governments. This new concept is shown in Figure 4. 


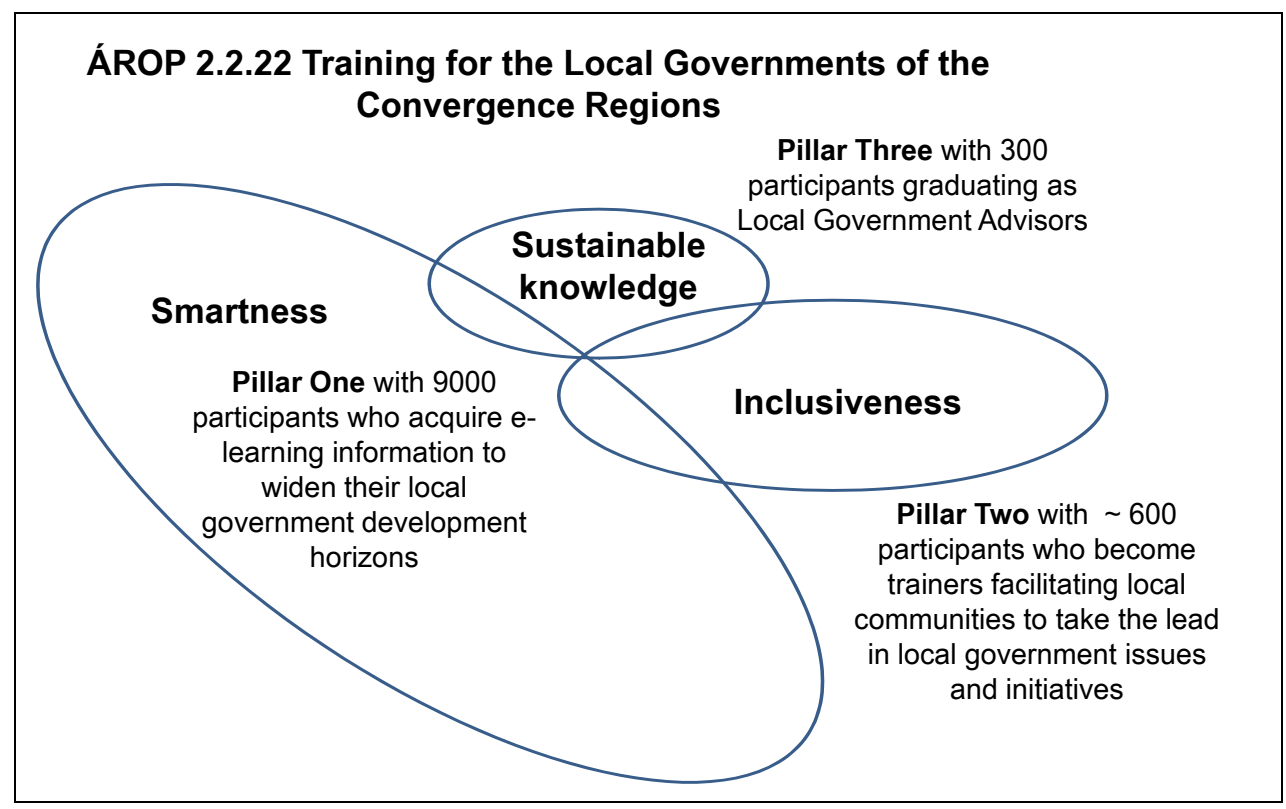

Figure 4. Realization of the Flagship Program (New Approach Post Graduate Training of Civil Servants) meeting the requirements of Europe 2020 Directive and the call of modernization both in technological and social aspects

\section{Completion of Pillar One: Sustainable Local Government}

From 1 March 2014 till the end of the year 22.563 civil servants registered themselves in any of the 6 modules of Pillar One. The program's indicator was 9 thousand students from the convergence regions of Hungary. Not considering the central region, there were 15.659 registered students out of which 14.653 accomplished one or several modules from the e-learning program. It means that the indicator of the pillar was $163 \%$ successful.

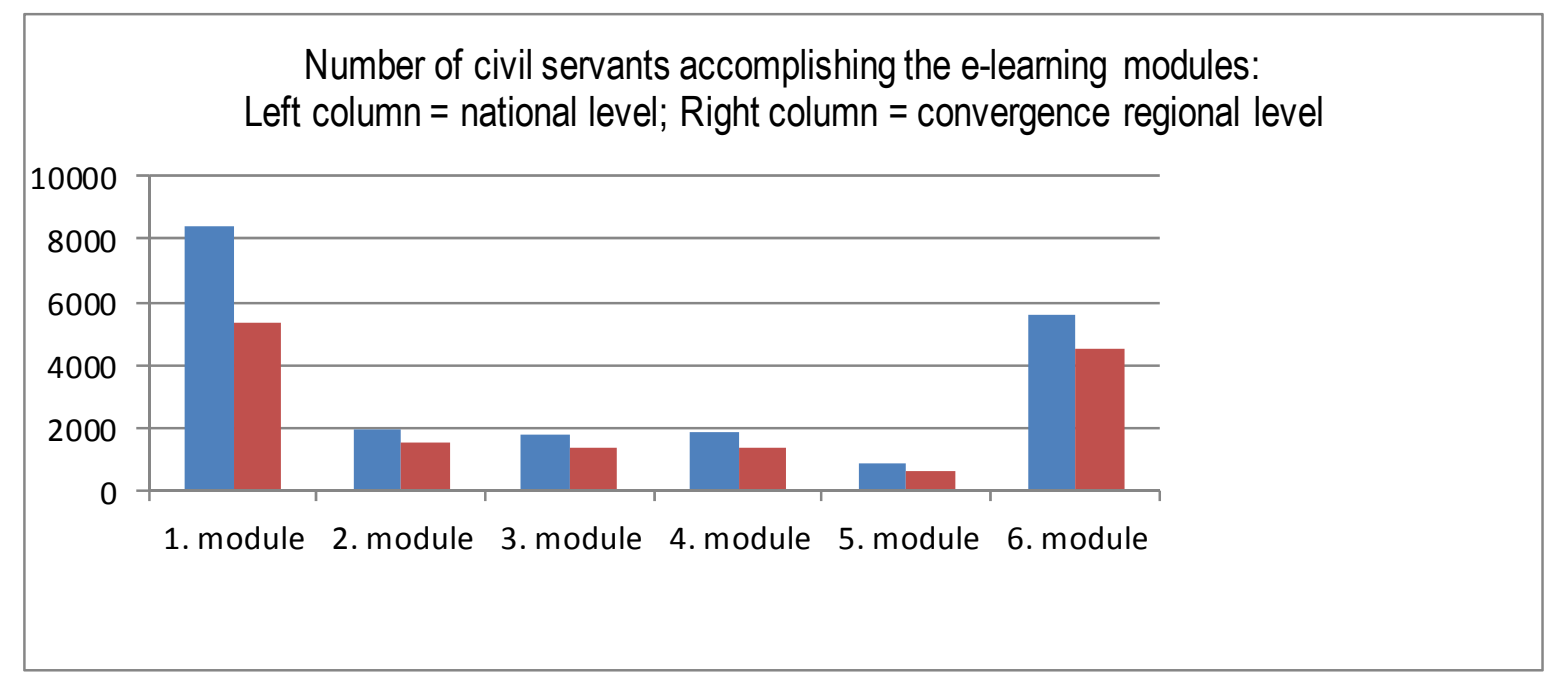

Diagram 1. The popularity of the module topics is reflected in the diagram: conflict management and local government financing and task performance attracted most of the students 

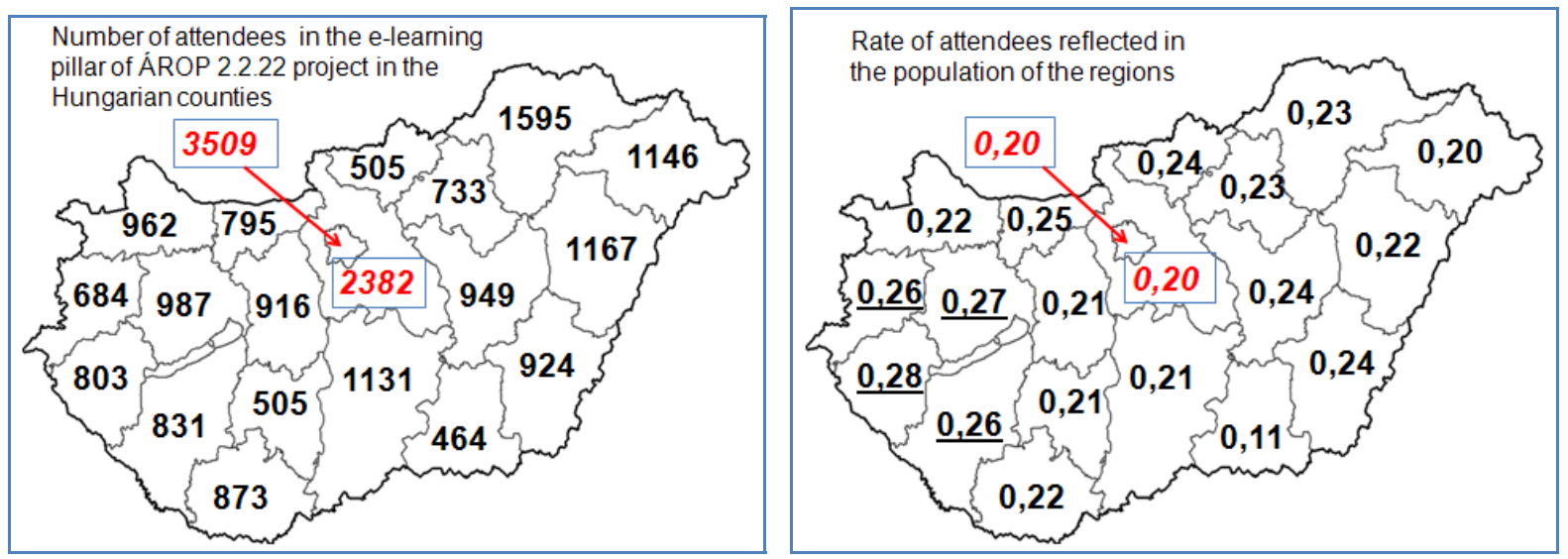

Figure 5. The participation in the e-learning pillar of the program in Hungarian counties

Framed numbers show the capital city (Budapest) and the central region (Pest County). From the maps the willingness and readiness of the public servants towards smart forms of post graduate training can be interpreted which is especially strong in the West - Southwest counties of Transdanubia (see the numbers underlined on the right).

Around one hundred civil servant students registered themselves for each of the five conferences. All the lectures of the conferences are available online for the students. The $5 \mathrm{x}$ 6 lecturers of the regional presentations were asked to submit their presentations in the form of studies, so the program management succeeded in publishing five conference study volumes both in printed and online versions.

\section{Completion of Pillar Two: Local Community Academy}

The accomplishment of the Local Community Academy (LCA) took place from September 2014 to March 2015 and on the basis of the number of attendees and their activity it can be considered a success story. Compared to the anticipated $\sim 600$ participants there were all together 2984 of them and instead of 70, finally 77 small settlements were accepted to join the Local Community Academy Pillar. It means that some 20 to 50 participants arrived from each of the settlements.

The immediate impacts of the Pillar can be grouped into three categories:

1. Accomplished documents of Development Strategy
2. Web activity

on the Pillar's website
3. Mental benefits in local community building

1. Out of the 77 settlements 74 succeeded in elaborating strategic documents which is $97 \%$. There were 46 completed development strategies and 28 collections of documents capable of being turned into acceptable strategies. This output is very significant, especially if the size and dimension of the settlements are considered. Such small settlements are very rare to afford development strategies. So this Pillar activated the power of local social inclusiveness 
in accomplishing a local government task that would have required otherwise experts and extra resources outside of the settlement.

2. A total 945 entries were written by the participants up to 1 March 2015 on topics like news (97), introductions of participating settlements, consultations, institutional background, legal grounds, existing strategies, methodology, special literature and publications (145), best practices home (376), best practices abroad, samples in strategy making. These figures again prove the power hidden in local inclusiveness that can be mobilized in favor of local development as a local government task.

3. There are other effects of the Pillar the importance of which are difficult to measure, and they are manifested in various ways and aspects.

Local community building by LCAs

A previously formed community accommodated LCA
The LCA emerged as a new community
The formation of a new

LCA community is under way
No new LCA community emerged

in $8 \%$ of all LCAs $\quad$ in $34 \%$ of all LCAs in $31 \%$ of all LCAs

in $27 \%$ of all LCAs

Web penetration by $L C A s$

\begin{tabular}{ccc}
\hline $\begin{array}{c}\text { New LCA Face Book } \\
\text { profile was opened }\end{array}$ & $\begin{array}{c}\text { Previously formed Face Book profiles } \\
\text { accommodated LCA }\end{array}$ & $\begin{array}{c}\text { No LCA Face Book } \\
\text { Profile was created }\end{array}$ \\
\hline in $20 \%$ of all LCAs & in $30 \%$ of all LCAs & in $50 \%$ of all LCAs \\
\hline Medium effect: $50 \%$ & $50 \%$ \\
\hline
\end{tabular}

The local government accepts the LCA development strategy

\begin{tabular}{ccc}
\hline Yes & Partially & No \\
\hline in $73 \%$ of all LCAs & in $20 \%$ of all LCAs & in $7 \%$ \\
\hline & Very strong effect: $93 \%$ & $7 \%$ \\
\hline
\end{tabular}


Multiplicative effect of LCAs (Initiation of other local actions took place after the LCA project: e.g. online questionnaire survey, local meetings, and new civil organizations, involvement of local age or minority groups, new proposals)

\begin{tabular}{cc}
\hline Yes & No \\
\hline Medium effect: $55 \%$ & $45 \%$ \\
\hline
\end{tabular}

Further demand was generated towards LCA

\begin{tabular}{cc}
\hline Yes & No \\
\hline Medium effect: $64 \%$ & $36 \%$ \\
\hline
\end{tabular}

Children inclusion (Was there e.g. a recommended children's drawing competition event organized in the course of the LCA?)

\begin{tabular}{cc}
\hline Yes & No \\
\hline Low effect: $20 \%$ & $80 \%$ \\
\hline
\end{tabular}

Neighborhoods inclusion (Did the representatives of the neighboring settlements show interest towards LCA?)

$\begin{array}{cc}\text { Yes } & \text { No } \\ \text { Medium: } 40 \% & 60 \%\end{array}$

Home municipality support (According to the trainer: was there an open and supporting behavior on behalf of the local government representatives?)

\begin{tabular}{cccc}
\hline High & Medium & Low & None \\
\hline in 58\% of all LCAs & in 23\% of all LCAs & in 14\% of all LCAs & in 5\% of all LCAs \\
\hline & Strong effect: $95 \%$ & $5 \%$ \\
\hline
\end{tabular}




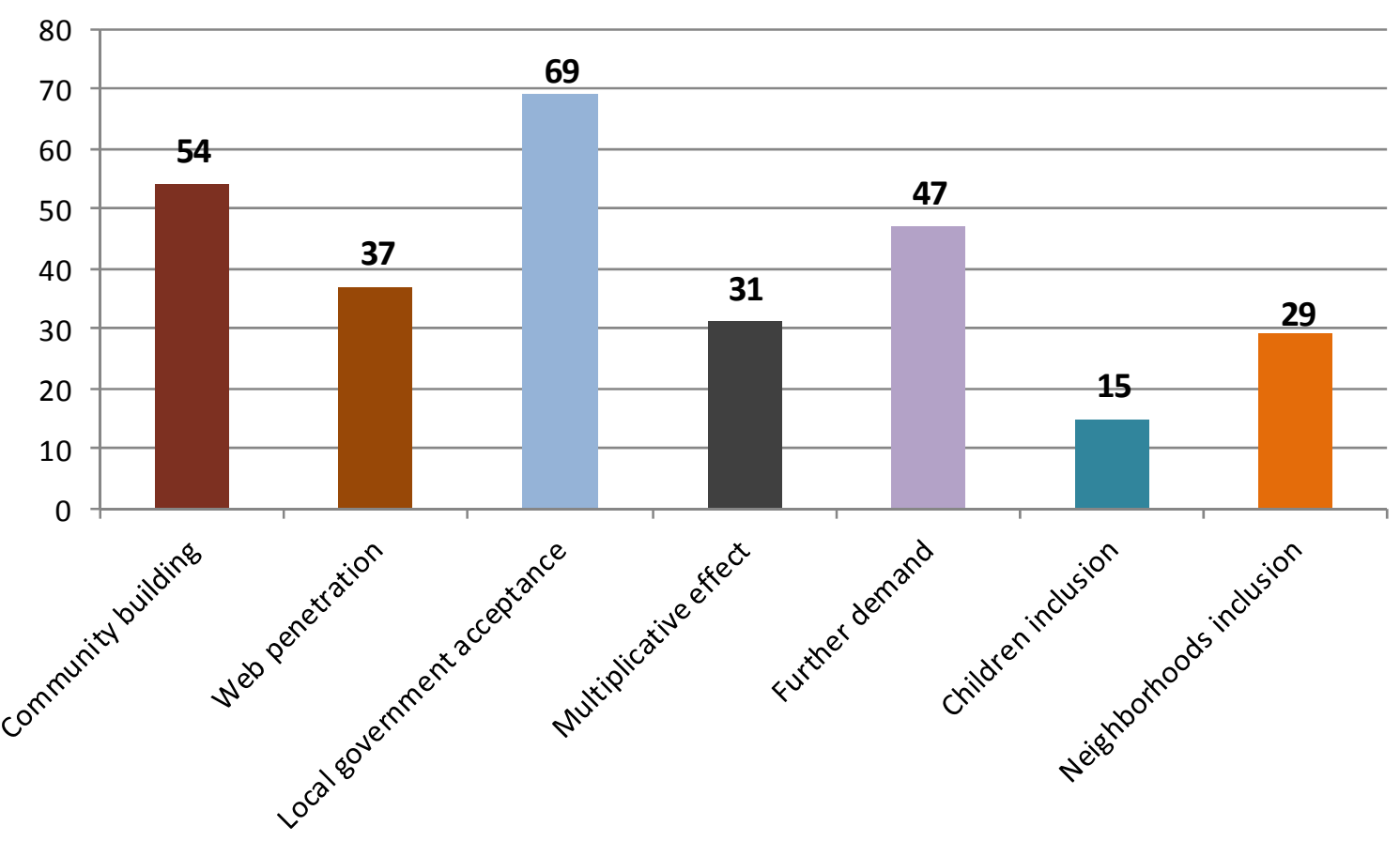

Figure 6. The mental beneficial impacts of the Local Community Academy training in the 74 participating settlements

\section{Completion of Pillar Three: Local Government Advisor}

307 public service officers registered themselves for the traditional classroom training in 2013. The first semester of the training was launched in February 2014 and the second semester lasted from September to December. Diploma works were accomplished in January, and the graduation took place in February 2015. Exactly 300 civil servants graduated. The teaching materials (the 12 textbooks) were accessible for the students online before the final exams in January. The 12 book were published in paper format in February 2015 in 300 copies each.

The students graduated from this flagship program were taken up into an inventory of the National University of Public Service entitled Local Government Advisor in order to rely on them in case of relevant projects.

\section{Conclusion}

Unlike the previous post graduate training organized for local government officers, this training has been the most complex one uniting various devices from e-learning via traditional classroom training to a socially inclusive interactive training that supports local community building for the sake of a well operating local government. 
As an integrated output of the program there is a Network of Local Government Academies (HKA) that can serve in the future as the basis of further development. The HKA stands for a brand with its website serving the network functions with information about workshops, news desks, partnership connections, references of best practices, etc. A methodological document was written as a guidebook of how to establish HKA-s. This is the guidebook of local strategy-making. Actually all the three pillars of the project yielded such guide books like how to organize the e-learning modules and the training of the local government experts. The guide book methodology of the HKA within this program was tried and applied at 77 localities in practice. These applications brought about the process of the methodology of strategy-making at last. Another result of the project includes the training of $\mathbf{4 0}$ trainers as a staff capable to include, organize and direct the active members of local society with focusing their energy in initiating and accomplishing local development project. Some of these 40 trainers also belong to the $\mathbf{3 0 0}$ local government advisers who can also take an active part in local development projects.

The HKA website serves as a knowledge center for local development due to its huge collection of best practices, special literature and other useful project information. All the accomplished documents of local strategy are accessible in the HKA website, including their evaluations and assessments, proposals. All the participants produced online inquiries the findings of which are also available, sharing the information of the social receptiveness to development issues. The photos and videos taken during the training help the improvement of the HKA reputation. The HKA provided an experimental field for the 300 local government advisors who were trained in Pillar 3. An all the approximately 600 participants of Pillar 2 and the 300 attendees of Pillar 3 had studied one or several e-learning modules of Pillar 1. The proposals formed after the accomplishment of Pillar 2 (HKA) will contribute a great deal to the future training programs based on interactivity and inclusiveness. The HKA supports the formation of civil, local and central government and higher educational partnerships in local development issues.

This Local Community Academy, as one of the chief results of the program, is candidate for the European Public Sector Award (EPSA) 2015 as a best practice in the new type of socially inclusive training contributing to local development strategies and issues.

The significance of this program lies in its easy responsiveness to legal changes occurring in the fields of local governments. The elements of it pillars are easily capable of updating and the replacement of information is quick either in the e-learning modules or the traditional teaching material or the trainers' methods, attitudes and the contents of the training, too. Meeting the teaching material (i.e. how local government works under the ever changing social and political environment in Central and Eastern Europe) on different platforms, in the form of completely different methods makes the student acquire knowledge in a more efficient way than during the previous training programs - we believe.

\section{References}

Belényesi E., \& Dobos Á. (2010). Post Graduate Training in Public Administration Methodological Alternatives in an Empiric Approach (in Hungarian: Közigazgatási 
továbbképzések - módszertani alternativák egy empirikus vizsgálat tükrében $)=U_{j}$ Magyar Közigazgatás, 11, 19-26.

Dobos Á. (1998). Guide to the Local Government Training (in Hungarian: Útmutató az önkormányzati képzéshez - interaktív módszerek és technikák) ICMA (International City County Management Association) Hungarian Public Administration Project, Budapest, Hungary.

Dobos Á. (2009a). Efficiency of Interactive Adult Training (in Hungarian: Az interaktív felnöttképzés eredményességének kérdése a tréning módszer tükrében) $=$ Felnöttképzés $2, \mathrm{pp}$ 42-48.

Dobos Á. (2009b). The Facilitative Adult Trainer Role = Practice and Theory in Systems of Education, 1, 67-78. Retrieved from www.eduscience.hu

Dobos Á. (2011a). Public Administration Academy in the USA (in Hungarian: Közszolgálati akadémia az Amerikai Egyesült Államokban) = Pro Bono Publico, 1, 109-115.

Dobos Á. (2011b). The American Public Administration Programs Viewed from Hungary (in Hungarian: Magyar szemmel - Amerikai közigazgatási programok a világban) = Önkormányzat 1-2., pp 23-25. Retrieved from www.toosz.hu

Dobos Á. (2011c). Exemplary Best Practice or Benchmarking in Local Government Practice (in Hungarian: Példát adó jó gyakorlat, avagy benchmarking az önkormányzás gyakorlására) = Pro Publico Bono Online 1. Retrieved from http://www.propublicobono.hu/index.php?list $=2 \& b=1 \& \operatorname{mode}=3$

Europe 2020. Europe 2020 in a nutshell: Priorities. Retrieved from http://ec.europa.eu/europe2020/europe-2020-in-a-nutshell/priorities

Fearn, H. (2013). Council staff lack skills to commission public services - Report on the survey conducted by the Guardian Local Government Network. Retrieved from http://www.theguardian.com/local-government-network/2013/jan/14/council-staff

Government Decree (2012). No. 273/2012 (IX. 28) on the Post graduate training of civil service officers in Hungary.

HEFOP-3.3.1 Final Report 2008. Structural and content development of higher education. Innovation in higher education and post graduate expert training (in Hungarian: $A$ felsőoktatás szerkezeti és tartalmi fejlesztése - A felsőfokú közigazgatási szakemberképzés szerkezeti és tartalmi megújítása) Ed: Tóth J. Budapesti Corvinus Egyetem Közigazgatás-tudományi Kar

Tóth, J. J. (2007). State Administration Institute (in Hungarian: Államigazgatási Továbbképző Intézet. 1977 - 1997. In: A Budapesti Corvinus Egyetem Közigazgatás-tudományi Karának Államigazgatási Főiskola története 1977-2007. Ed. Orosz Á.) Budapest, HVG-ORAC pp 152-169 


\section{Copyright Disclaimer}

Copyright for this article is retained by the author(s), with first publication rights granted to the journal.

This is an open-access article distributed under the terms and conditions of the Creative Commons Attribution license (http://creativecommons.org/licenses/by/3.0/). 